\title{
Learning Curve at Laparoscopic Colorectal Surgery
}

\section{Laparoskopik Kolorektal Cerrahide Öğrenme Eğrisi}

\author{
(1) Eyüp Murat Yılmaz¹, (1) Erkan Karacan² \\ ${ }^{1}$ Adnan Menderes University Faculty of Medicine, Department of General Surgery, Aydın, Turkey \\ ${ }^{2}$ Aydın State Hospital, Clinic of General Surgery, Aydın, Turkey
}

\section{HIIIIIII ABSTRACT}

Aim: The learning curve at laparoscopic colorectal surgery is a long and laborious process. Therefore, despite its advantages, it cannot still be accepted as the gold standard procedure. The purpose of this study is to compare the effect of learning curve at laparoscopic colorectal surgeries performed begining period and surgeries after getting experienced.

Method: All cases who underwent laparoscopic colorectal surgery in Adnan Menderes University Department of General Surgery between December 2014 and May 2019 were included in the study. The study was divided into two groups as the first time cases and the cases after the completion of the learning curve. The files of the cases were scanned and demographic data, types of operations, operation times, postoperative complications, oral intake times in the postoperative period, length of hospital stay, and number of extracted lymph nodes were recorded. The numbers of both groups were compared statistically.

Results: A total of 102 patients were included in this study and 71 (69.6\%) of these patients were included in Group 1 and 31 (30.4\%) of these patients were included in Group 2. In terms of the duration of operations, the mean duration of operation was $149.2 \pm 28.14$ minutes in Group 1 and $87.16 \pm 13.98$ minutes in Group 2 ( $\mathrm{p}=0.001$ ). There were no statistically significant differences in the duration of hospitalization and oral intake in the postoperative time in both groups. The number of extracted lymph nodes was $16.27 \pm 4.94$ in Group 1 and $21.81 \pm 5.45$ in Group 2 (p=0.001).

Conclusion: When experience increases in laparoscopic colorectal surgery, morbidity rate decreases and more complicated cases can be operated in a shorter time.

Keywords: Colorectal surgery, learning curve, laparoscopy

\section{|IIIIIII| ÖZ}

Amaç: Laparoskopik kolorektal cerrahide ögrenme eğrisi uzun ve zahmetli bir süreçtir. Bu sebeple birçok avantajına rağmen halen günümüzde altın standart olarak kabul edilememektedir. Bu çalışmadaki amacımız laparoskopik kolorektal cerrahideki öğrenme eğrisinin ilk başlangıcındaki ve tecrübe kazandıktan sonraki zamandaki ameliyatlar üzerine etkisinin karşılaştırılmasıdır.

Yöntem: Adnan Menderes Üniversitesi Kolorektal Bölümü'nde Aralık 2014- Mayıs 2019 tarihleri arasında laparoskopik kolorektal cerrahi uygulanmış tüm olgular çalışmaya dahil edildi. Çalışma, ilk başlanan olgular ve eğitim eğrisinin tamamlandı̆̆ı olgular olarak 2 gruba ayrıldı. Olguların dosyaları taranıp demografik verileri, ameliyat çeşitleri, ameliyat süreleri, ameliyat sonrası gelişen komplikasyonlar, postoperatif dönemde oral alıma geçiş günleri, hastanede yatış süreleri, çıkartılan lenf nodu sayıları kaydedildi ve her iki grubun sayıları istatistiksel olarak karşılaştırıldı.

Bulgular: Çalışmaya toplam 102 hasta dahil edilmiş olup 71'i $(\% 69,6)$ grup 1, 31'i ise $(\% 30,4)$ grup 2'ye dahildir. Ameliyat sürelerine bakıldığında ise grup l'de ortalama süre $149,2 \pm 28,14$, grup 2'de ise $87,16 \pm 13,98$ dakika bulunmuştur ( $\mathrm{p}=0,001$ ). Her iki grupta orala başlama ve hastanede yatış sürelerinde istatistiksel olarak anlamlı bir farklılık bulunmaz iken, çıkartılan lenf nodu sayısına bakıldığında grup l'de 16,27 $\pm 4,94$, grup 2'de $21,81 \pm 5,45$ olarak saptanmıştır ( $\mathrm{p}=0,001)$.

Sonuç: Laparoskopik kolorektal cerrahide tecrübe arttıkça ameliyatta morbidite oranı azalmakta ve daha kısa sürede daha komplike olgular yapilabilmektedir.

Anahtar Kelimeler: Kolorektal cerrahi, öğrenme eğrisi, laparoskopi

Address for Correspondence/Yazışma Adresi: Erkan Karacan MD,

Aydın State Hospital, Clinic of General Surgery, Aydın, Turkey

E-mail: erkan8806@gmail.com ORCID ID: orcid.org/0000-0001-8081-5944

Received/Geliş Tarihi: 22.11.2019 Accepted/Kabul Tarihi: 19.12.2019

${ }^{\circ}$ Copyright 2020 by Turkish Society of Colon and Rectal Surgery

Turkish Journal of Colorectal Disease published by Galenos Publishing House. 


\section{Introduction}

Laparoscopic colorectal surgery has been evolving procedure since the early 1990s, especially with the development of laparoscopic staplers. ${ }^{1,2}$ As it is known, laparoscopic colorectal surgery is a procedure in which the duration of hospitalization is shorter compared to open surgery, the analgesic requirement in the postoperative period is less needed, better cosmetic results are obtained and the gastrointestinal system can work more quickly. ${ }^{3}$ However, despite the fact that colorectal surgery has many advantages and low morbidity rates, it is still not considered as the gold standard procedure among colorectal surgeons. ${ }^{4}$ One of the reasons for this is probably the fact that the learning curve is long and steep. ${ }^{5}$

The purpose of this study is to compare the effect of learning curve at laparoscopic colorectal surgery on the first time surgeries and surgeries after gaining experience.

\section{Materials and Methods}

All cases who underwent laparoscopic colorectal surgery in Adnan Mendres University Department of General Surgery between December 2014 and May 2019 were included in the study. This study was approved by local ethical committee. All cases were performed by the same general surgeon and his team.

The cases that were performed between December 2014 and January 2018 were evaluated as Group 1, and after gaining experience, the cases which were published in the literature between January 2018 and May 2019 were evaluated as group 2 . The cases including conversion to open surgery were excluded from study. The files of the cases were scanned and demographic data, types of operations, operative times, postoperative complications, oral intake times in the postoperative period, length of hospital stay, and number of extracted lymph nodes were recorded. The numbers of both groups were compared statistically.

\section{Statistical Analysis}

SPSS 25 (IBM Corp. Released 2017. IBM SPSS Statistics for Windows, Version 25.0. Armonk, NY: IBM Corp.) statistical package program was used to evaluate the data. Variables were expressed using mean \pm standard deviation, percentage and frequency values. Variables were evaluated (Shapiro Wilk and Levene test) after normalization, after homogeneity of variances was checked. In the analysis of data, student's t-tests were used for the comparison of two groups. When student's t-test did not provide preconditions, the Mann-Whitney U test was used. Categorical data were analysed by the Fisher's exact test and chi-square test. When the expected frequencies were less than $20 \%$, the Monte Carlo Simulation method was used for the inclusion of these frequencies in the analysis. The value of $p<0.05$ was accepted as significant.

\section{Results}

A total of 102 patients were included in this study and 71 (69.6\%) of these patients were included in group 1 and 31 (30.4\%) were included in group 2 . The mean age of group 1 was $68.76 \pm 9.05$ years, and the mean age of group 2 was $65.06 \pm 12.52$ years $(p=0.001)$. There were statistically no significant differences in the duration of hospitalization and oral intake in the postoperative time in both groups. The number of extracted lymph nodes was $16.27 \pm 4.94$ in group 1 and $21.81 \pm 5.45$ in group $2(\mathrm{p}=0.001)$ (Table 1$)$. In terms of the duration of operations, the mean duration of operation was $149.2 \pm 28.14$ minutes in group 1 and $87.16 \pm 13.98$ minutes in group $2(\mathrm{p}=0.001)$.

Complications occurred in six patients. Five of these patients (83.3\%) were in group 1 and one (16.7\%) was in group $2(\mathrm{p}=0.689)$. No complication was observed in 96 cases. Transrectal anterior resection was performed with natural orifice transluminal endoscopic surgery (NOTES) technique to a patient in group 2. No mortality was observed in both groups (Table 2).

\section{Discussion}

Advanced laparoscopic surgery has been used safely in many procedures recently but it is still not considered as the gold standard in colorectal surgery. ${ }^{6,7}$ One of the probable reasons for this is the fact that the learning curve is long and steep. ${ }^{5}$ The laparoscopic colorectal surgery, which is known to have more advantages than open surgery, provides significant benefit in obese, high ASA score and old patients. ${ }^{8}$

Because the learning curve in laparoscopic colorectal surgery is long and difficult, the benefit of simulation courses on cadavers and animals is quite good for the surgeon. ${ }^{9} \mathrm{COLOR}$ is the most known one studied at laparoscopic colorectal surgery. ${ }^{10}$ In our country, it is thought that the initiatives and contributions of many associations and professional

Table 1. No mortality was observed in both groups

\begin{tabular}{llll} 
& Before & After & \\
& $\mathbf{n}=71$ & $\mathrm{n}=31$ & $\mathrm{p}$ \\
\hline Age & $68.76 \pm 9.05$ & $65.06 \pm 12.52$ & 0.100 \\
Operation time & $149.2 \pm 28.14$ & $87.16 \pm 13.98$ & $0.001^{* *}$ \\
Hospitalization & $7.77 \pm 14.51$ & $4.9 \pm 1.11$ & 0.280 \\
Oral intake & $1.7 \pm 0.6$ & $1.65 \pm 0.55$ & 0.640 \\
Lymph node & $16.27 \pm 4.94$ & $21.81 \pm 5.45$ & $0.001^{* *}$ \\
$* *: \mathrm{p}<0.01$ & & &
\end{tabular}


groups on this subject have important contributions to many young surgeons. Many publications and studies show that an experienced surgical team reduces operation time, conversion to open surgery and complication rate. ${ }^{11}$ According to the study conducted by Li et al. ${ }^{12}$, after 6080 series on laparoscopic colorectal surgery, surgical acceleration, morbidity and decrease in complication were observed in cases. Simon et al. ${ }^{13}$ described this learning curve in 30-70 cases, while Bennet et al. ${ }^{14}$ described in $10-40$ cases. In this study, after 70 cases, the duration of the operation was shortened and the number of removed lymph nodes increased. There was no statistically significant difference in the complication rate.

In some studies, the rate of conversion from laparoscopic surgery to open surgery was $7-25 \%$ and in some studies, it was reported as $2-41 \% .{ }^{15,16}$ In this study, the cases with conversion to open surgery from laparoscopic surgeries were excluded from the study because these data were not recorded. That is one of the important limitations of the study. In order to evaluate this study more meaningfully,

Table 2. Comparison of complications between the two groups

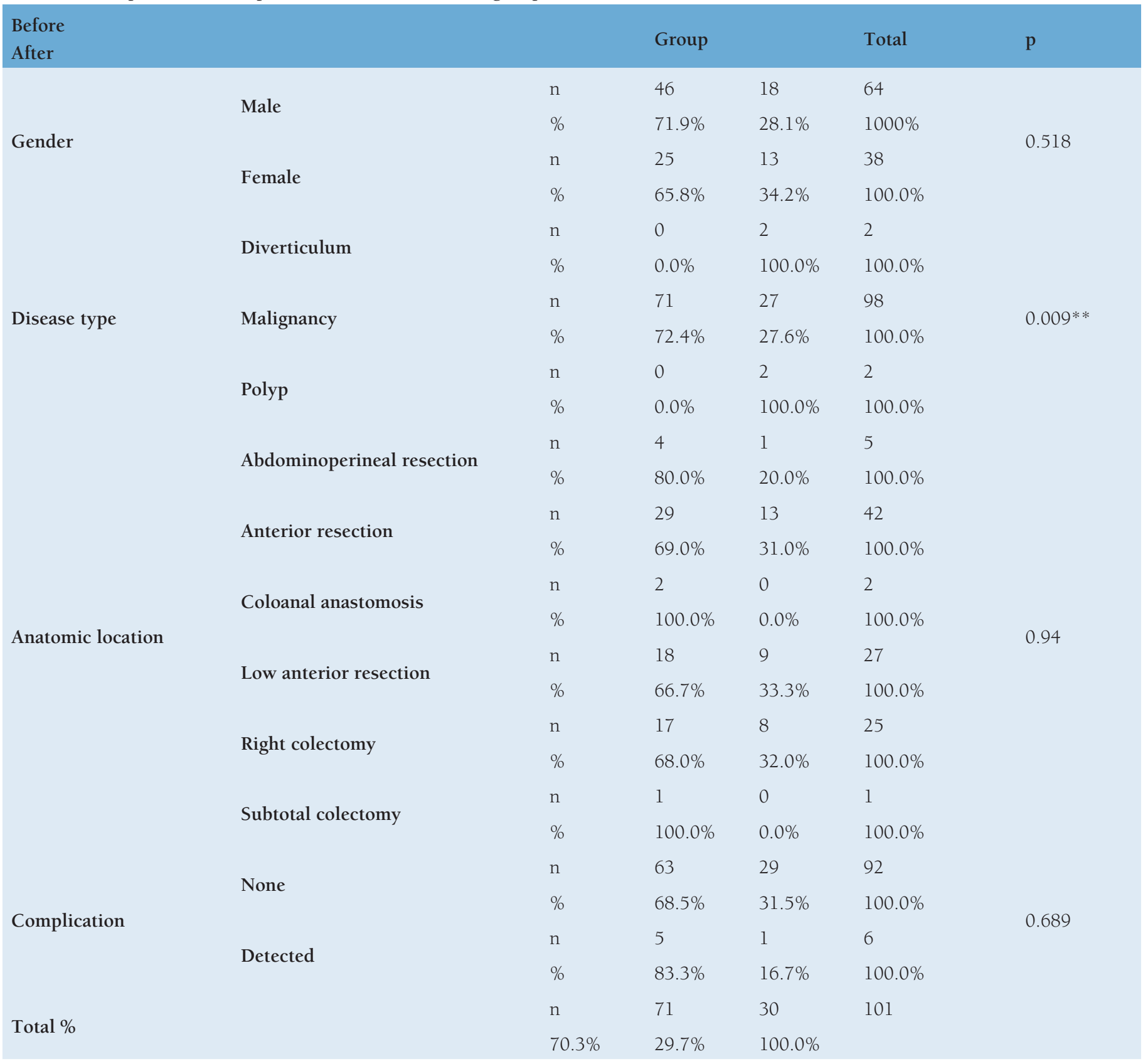


it is thought that prospective planning in a new beginning centre and the rates of conversion to open surgery from laparoscopic surgery should be included in these studies.

Patient selection is one of the most important factor when beginning laparoscopic colorectal surgery. ${ }^{17}$ Dinçler et al. ${ }^{18}$ suggest that the study curves should be started with sigmoid colectomies with no Body Mass index without comorbidity. It is stated that they can continue the series with more complicated and mixed cases in later periods. Especially when surgeons gain experience, they can also be more liberal in the use of laparoscopy in cases of diverticular disease and diverticulitis attack. ${ }^{19}$ In this study, there were no diverticular disease in group 1 , and 2 patients in group 2 had diverticulitis. Again, expanding the policy of liberalism slightly, first NOTES transrectal anterior resection case was applied in Group 2.

Many studies in the literature show that intraoperative and postoperative complication rates in laparoscopic colorectal surgery decrease with increasing experience..$^{20,21}$ In this study, it was observed that postoperative complication rate decreased as the experience increased but it was not statistically significant. Again, adequate oncologic lymphatic dissection was performed in both groups, but it was thought that total mesocolic and total mesorectal excision would be better with the increasing experience. As a result of this study, the learning curve in laparoscopic colorectal surgery is a long and time-consuming process, and with an increase in the experience of the surgeon, more complex cases can be coped with.

\section{Study Limitations}

Because of our patients' low number, we have to add our patients in our study. So, we cannot classify the patients for their surgery types.

\section{Conclusion}

With the increase experience of surgeon, more complicated cases can be operated in shorter time with low morbidity rate.

\section{Ethics}

Ethics Committee Approval: This study was approved by local ethical committee.

Informed Consent: Retrospective study.

Peer-review: Internally peer reviewed.

\section{Authorship Contributions}

Surgical and Medical Practices: E.M.Y., Concept: E.M.Y., Design: E.K., Data Collection or Processing: E.M.Y., E.K., Analysis or Interpretation: E.M.Y., E.K., Literature Search: E.M.Y., E.K., Writing: E.M.Y., E.K.

Conflict of Interest: No conflict of interest was declared by the authors.
Financial Disclosure: The authors declared that this study received no financial support.

\section{References}

1. Shah P, Joseph A, Haray P. Laparoscopic colorectal surgery: learning curve and training implications. Postgrad Med J 2005;81:537-540.

2. Yllmaz EM, Cartı EB, Kandemir A. Our Experience of Laparoscopic Colorectal Surgery: Short Term Outcomes. Turk J Colorectal Dis 2016;26:108-112.

3. Kalfaoğlu M, Hansel H, Cevheroğlu C, Gürkut Ö, Ciner F, Beroval Ö, Müderriszade M, Yavuz N. KKTC'de Laparoskopik Kolorektal Cerrahi Deneyimimiz. Kolon Rektum Hast Derg 2013;23:157-161.

4. Luglio G, Domenico De Palma G, Tarquini R, Cesare Gigluo M, Sollazzo V, Esposito E, Spadarella E, Peltrini R, Liccardo F, Bucci L. Laparoscopic colorectal surgery in learning curve: Role of implementation of a standardized technique and recovery protocol. A cohort study. Ann Med Surg (Lond) 2015;4:89-94.

5. Bardakcioglu O, Khan A, Aldridge C, Chen J. Growth of laparoscopic colectomy in the United States: analysis of regional and socioeconomic factors over time. Ann Surg 2013;258:270-274.

6. Ivatury SJ, Bostock Rosenzweig IC, Holubar SD. Short-term Outcomes After Open and Laparoscopic Colostomy Creation. Dis Colon Rectum 2016;59:543-550

7. Attaallah W, Babayev H, Yardımcı S, Cingi A, Uğurlu MÜ, Günal Ö. Laparoscopic resection for colorectal diseases: short-term outcomes of a single center. Ulus Cerrahi Derg 2016;32:199-202.

8. Hemandas AK, Abdelrahman T, Flashman KG. Laparoscopic colorectal surgery produces better outcomes for high risk cancer patients compared to open surgery. Ann Surg 2010;252:84-89.

9. Mackenzie H, Miskovic D, Ni M. Clinical and educational proficiency gain of supervised laparoscopic colorectal surgical trainees. Surg Endosc 2013;27:2704-2711.

10. E. J. Hazebroek, COLOR study group. Surgical Endoscopy And Other Interventional Techniques 2002, Volume 16, Issue 6, 949-953

11. Bennett CL, Stryker Sj, Ferreira MR, Adams J, Beart RwJr. The learning curve for laparoscopic colorectal surgery: preliminary results from a prospective analysis of 1194 laparoscopic-assisted colectomies. Arch Surg 1997;132:41-44.

12. Li JC, Hon SS, Ng SS, Lee JF, Yiu RY, Leung KL. The learning curve for laparoscopic colectomy: experience of a surgical fellow in an university colorectal unit. Surg Endosc 2009;23:1603-1608.

13. Simons AJ, Anthone GJ, Ortega AE, Franklin M, Fleshman J, Geis WP, Beart RW Jr. Laparoscopic-assisted colectomy learning curve. Dis Colon Rectum 1995;38:600-603.

14. Bennett CL, Stryker SJ, Ferreira MR, Adams J, Beart RW. The learning curve for laparoscopic colorectal surgery: preliminary results from a prospective analysis of 1194 laparoscopic-assisted colectomies. Arch Surg 1997;132:41-44.

15. Gervaz P, Pikarsky A, Utech M, Secic M,Efron J, Belin B, Jain A, Wexner S. Converted laparoscopic colorectal surgery. Surg Endosc 2001;15:827-832.

16. Marusch F, Gastinger I, Schneider C, Scheidbach H, Konradt J, Bruch HP, Köhler L, Bärlehner E, Köckerling F; Laparoscopic Colorectal Surgery Study Group (LCSSG). Importance of conversion for results obtained with laparoscopic colorectal surgery. Dis Colon Rectum 2001;44:207-214.

17. Tekkis PP,Senagore AJ, Delaney CP, Fazio VW. Evaluation of the Learning Curve in Laparoscopic Colorectal Surgery. Ann Surg 2005;242:83-91.

18. Dincler S, Koller MT, Steurer J, Bachmann LM, Christen D, Buchmann P. Multidimensional analysis of learning curves in laparoscopic sigmoid resection: eight-year results. Dis Colon Rectum 2003;46:1371-1378. 
19. Agachan F, Joo JS, Weiss EG, Wessner DS . Intraoperative laparoscopic complications: are we getting better? Dis Colon Rectum 1996;39(suppl):14-19.

20. Marusch F, Gastinger I, Schneider C, Scheidbach H, Konradt J, Bruch HP, Bruch HP, Köhler L, Bärlehner E, Köckerling F; Laparoscopic Colorectal Surgery Study Group (LCSSG). Experience as a factor influencing the indications for laparoscopic colorectal surgery and the results. Surg Endosc 2001;15:116-120

21. Schlachta CM, Mamazza J, Seshadri PA, Caddeddu OM, Poulin EC. Predicting conversion to open surgery in laparoscopic colorectal resections: a simple clinical model. Surg Endosc 2000;14:1114-1117. 